\title{
MANAJEMEN KONFLIK PADA PERUSAHAAN KELUARGA (STUDI KASUS PADA PERKEBUNAN X)
}

\author{
Yolla Margaretha \\ Program Studi Manajemen, Fakultas Ekonomi, Unversitas Kristen Maranatha, Bandung \\ Email: yollamargaretha520182@gmail.com
}

Submitted: Mar 1, 2019; Reviewed: Mar 1, 2019; Accepted: Apr 4, 2019

\begin{abstract}
The economy of a country is supported by the role and contribution of entrepreneurs. They are the driving force for economic growth and one of them is contribution by family business. Even in some developed countries, family companies are the main source of their economy. However, internal management often creates conflicts, which can have a positive and negative impact. This will certainly affect the growth of the family company business. Therefore, good conflict management is needed to resolve conflicts. The role of family business stakeholders must be able to act and play a professional role. In this company, the root of the conflict is the inconsistency of communication between stakeholders in the company, thus triggering mismanagement and hampering the development of the company.
\end{abstract}

Keywords: Conflict; Family Business

\section{PENDAHULUAN}

Indonesia adalah negara yang sangat kaya. dianugerahi tanah yang subur membuat pertanian dan perkebunan di Indonesia menghasilkan panen yang melimpah. Kontribusi bidang perkebunan akan sangat memengaruhi pendapatan daerah maupun nasional.Salah satu perusahaan perkebunannya adalah Perkebunan X yang berada di Lembang, Jawa Barat, merupakan family business yang berdiri sejak 2008. Luas lahan yang dimiliki awalnya hanya dua hektar, dan di tahun 2019 luas lahan yang dimiliki sudah mencapai 13 hektar.

Perkebunan ini merupakan perkebunan stroberi premium hasil pembibitan ras luar negeri dan dalam negeri yang dibudidayakan di Jawa Barat. Hasil produksi perkebunan ini berkisar sekitar empat hingga delapan kuintal perbulan atau sekitar empat hingga sembilan ton per tahun. Besaran hasil produksi stroberi (masa panen) sangat tergantung oleh kondisi alam, kesehatan tanaman dan curah hujan yang memadai.Perkembangan bisnis perkebunan stroberi ini dari tahun ke tahun mengalami perkembangan yang sangat signifikan baik dari skala produksi maupun dari inovasi produknya.
Mereka terus menerus melakukan pengembangan produk, selain hasil produksi utama adalah buah stroberi segar, sekarang berkembang menjadi wisata alam stroberi di Jalan Raya Lembang, selai stroberi, cold press stroberi, jus stroberi dan permen stroberi.

Berdasarkan hasil penelitian yang dilakukan oleh Lucky, Minai, \& Isaiah (2011), bisnis keluarga adalah komponen pengembangan kewirausahaan dan aspek penting dari pembangunan ekonomi dan transformasi ekonomi yang menawarkan pekerjaan dan menciptakan kekayaan bagi keluarga dan orangorang lain yang bekerja di bisnis keluarga. Oleh karena itu, pendiri dan penerus akan berupaya semaksimal mungkin demi keberlangsungan hidup bisnis keluarga.

\section{RUMUSAN MASALAH}

Penelitian dalam bisnis keluarga telah berkembang pesat selama beberapa dekade terakhir. Daya tariknya adalah perjalanan bisnis keluarga tidak semulus yang diharapkan semua pihak. Konflik kerap kali ditemukan dengan kadar yang sering dalam bisnis keluarga. Hal ini diakibatkan pengelola perusahaan sebagian besar 
adalah anggota keluargadan seringkali kepentingan pribadi (keluarga) dan bisnis menjadi tumpang tindih.

Carr \& Hmieleski (2015) menyatakan dalam bisnis keluarga, konflik peran disebabkan oleh kenyataan bahwa anggota keluarga dihadapkan dengan kehadiran keluarga dalam pekerjaan dan kehidupan pribadi mereka, hal ini memberikan kontribusi pada ambigunya pekerjaan dan peran keluarga. Pada akhirnya, jenis konflik ini secara bertahap dapat menyebabkan tekanan pada kesehatan fisik dan psikologis pendiri bisnis misalnya menghasilkan ketegangan dalam pekerjaan, memengaruhi kemampuan mereka untuk berpartisipasi dalam kehidupan bisnis dan keluarga. Konflik yang terjaditentunya dapat menghambat proses manajemen sebuah perusahaan.

Tagiuri \& Davidmenciptakan model dua inti. Di mana dinamika bisnis keluarga dengan menciptakan dua lingkaran. Model ini disebut Model of the Two Nuclei (Tagiuri \& David, 1980; dalam Ruiz, 2013) ini mewakili dua inti yang dijelaskan di atas, unit keluarga, yang terletak di sisi kiri, dan pusat bisnis, terletak di sisi kanan untuk bergabung dan membuat area yang disebut "konflik zona", seperti yang dapat kita amati pada Gambar 1 berikut.

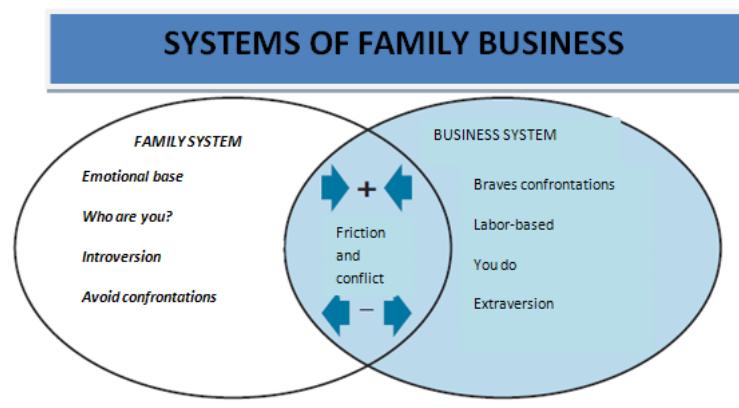

Gambar 1 Model of the Two Nuclei

Sumber: Tagiuri \& David (1980; dalam Ruiz, 2013)

Dampak negatif dari konflik dalam bisnis keluarga dipandang merusak siklus hidup perusahaan. Perusahaan keluarga cenderung menderita masalah yang berkaitan dengan nepotisme atau tim manajemen yang kurang memiliki keterampilan dan pengalaman. Konflik ini juga terrmasuk konflik hubungan pribadi di dalam keluarga misalnya dikarenakan ambisi untuk tetap memegang kendali perusahaan, juga konflik yang timbul antara keluarga danmanajer atau karyawan non-keluarga (Corbetta \& Salvato, 2012).
Memang tidak mudah mengetahui penyebab konflik secara detail, hal ini selaras dengan Xi et al., (2015) yang menyatakan konflik adalah bidang inti yang menjadi perhatian, pelaku bisnis tahu sedikit sekali tentang hal itu dan bahkan lebih sedikit tentang manajemen konflik dalam bisnis keluarga. Oleh karena itu dibutuhkan manajemen konflik agar bisa mengidentifikasi konflik, dan mendapatkan solusi dari konflik tersebut.

\section{TUJUAN PENELITIAN}

Tujuan penelitian ini adalah untuk mengetahui konflik yang timbul dalam perusahaan keluarga dan mengatasi konfliknya. Selain itu,penelitian ini mencari penyebab terjadinya konflik internal, dampak bagi perusahaan atas konflik internal, dan mekanisme penyelesaian masalah atas konflik internal pada perusahaan keluarga perkebunan.

\section{TINJAUAN PUSTAKA \\ Family Business}

Bagian ini menjelaskan tentang definisi dari perusahaan keluarga, konflik, manajemen konflik, strategi mengelola konflik, dampak konflik dan penyelesaian konflik. Perusahaan keluarga adalah suatu organisasi di mana terdapat dua atau lebih anggota keluarga yang mengawasi keuangan perusahaan (Aronoff et al., 2011). Donnelley (2002; dalam Nurwantoro \& Sobirin, 2013) mendefinisikan perusahaan keluarga yaitu sebuah organisasi yang paling sedikit ada keterlibatan dua generasi dalam keluargayang menjadi pemangku jabatan dalam perusahaan dan masing-masing pemangku jabatan tersebut akan memengaruhi kebijakan perusahaan.

Dalam Lucky et al., (2011) pengertian lain dari bisnis keluarga adalah komponen pengembangan kewirausahaan yang merupakan aspek penting dari pembangunan ekonomi dan transformasi ekonomi yang menawarkan pekerjaan dan menciptakan kekayaan bagi keluarga dan orang-orang lain yang bekerja di bisnis keluarga. Oleh karena itu, pendiri dan penerus akan berupaya semaksimal mungkin demi keberlangsungan hidup bisnis keluarga. Susanto (2007) mengatakan bisnis keluarga atau perusahan keluarga adalah sebuah organisasi yang di mana kepemilikan saham anggota keluarga minimal 25 persen.

Tipe-tipe perusahaan keluarga menurut Susanto (2007) adalah sebagai berikut:

a. Family Owned Enterprise (FOE) 
Family Owned Enterprise (FOE)merupakan perusahaan yang dimiliki oleh keluarga tetapi dikelola oleh eksekutif profesional yang berasal dari luar lingkungan keluarga. Dalam hal ini keluarga berperan sebagai pemilik dan tidak melibatkan diri dalam fungsi pengawasan.

b. Family Business Enterprise (FBE)

Family Business Enterprise merupakan perusahaan yang dimiliki dan dikelola oleh anggota keluarga pendirinya. Jadi baik kepemilikan maupun pengelolaan dipegang oleh pihak yang sama, yaitu keluarga. Perusahaan keluarga tipe ini dicirikan dan dipegangnya posisi kunci dalam perusahaan oleh anggota keluarga.

\section{Konflik}

Definisi konflik menurut Kamus Besar Bahasa Indonesia (2008) adalah bertentangan, berselisih paham, berbeda pendapat, tidak sejalan. Konflik dalam family business terjadi manakala dua orang atau kelompok atau lebih dalam keluarga mempunyai ide, pandangan, argumentasi, persepsi, dan pendapat yang berlawanan sehingga mereka saling menyalahkan yang berakibat buruk pada perusahaan.

Adapun dalam (Susanto, 2007) family business konflik dapat dikelompokkan menjadi tiga jenis.

a. Konflik Antara Kepentingan Bisnis dan Kepentingan Keluarga

Hal ini terjadi didasari oleh adanya perbedaan antara nilai-nilai keluarga dan nilai-nilai bisnis. Nilai dalam keluarga memiliki karakter inward looking (melihat ke dalam), keputusan dilakukan berdasarkan emosi, dan penerimaan tanpa syarat dari anggota keluarganya. Sementara nilai bisnis bersifat outward looking (melihat ke luar). Ikatan kerja bersifat komitmen dan kinerja. Sistem dan model bisnis harus mengikuti perkembangan jaman dan perusahan keinginan pasar sehingga sifatnya adaptif dan reaktif.

b. Konflik Antar Anggota Keluarga

Konflik dalam keluarga dapat dirangkum dalam 4 hal, yaitu konflik tujuan, gaya hidup dan kerja, konflik menyangkut kendali perusahaan, dan leaving the nest (meninggalkan rumah). Gaya hidup dan kerja berubah sepanjang waktu dan berbeda antara satu orang dengan orang lainnya, sehingga berpotensi menimbulkan konflik dalam keluarga. Keengganan untuk mengalihkan kendali perusahaan ke generasi penerus dari pendiri atau pemilik mengakibatkan konflik dalam keluarga dan perusahaan.

c. Konflik Antar Keluarga dan Karyawan

Konflik nilai antara keluarga dan karyawan biasanya terletak pada profesionalitas dan kepercayaan. Konflik ini terjadi disebabkan oleh miskomunikasi, gaya kepemimpinan, struktur organisasi dan sistem bisnis.Oleh sebab itu karyawan dituntut untuk bekerja dengan komitmen tinggi dan profesionalitas agar menumbuhkan trust (kepercayaan) kepada pemilik ataupendiri perusahaan.

\section{Manajemen Konflik}

Laurence \& Mustamu (2015) mengatakan agar konflik yang terjadi tidak semakin merambat dan menggangu keberlangsungan manajemen perusahaan bahkan sampai menjadi sulit terkontrol, maka diperlukan manajemen konflik yang antara lain melacak berbagai faktor penyebab konflik. Manajemen konflik harus dilakukan sejak konflik pertama kali muncul dalam perusahan. Manajemen konflik merupakan tindakan konstruktif yang direncanakan, diorganisasikan, digerakkan, dan dievaluasi secara teratur atas semua usaha demi mengakhiri konflik.

\section{Strategi Mengelola Konflik}

(Susanto, 2007) mengemukakan dalam mengelola konflik perusahaan dapat memilahnya menjadi lima strategi utama yaitu persaingan, penghindaran (avoidance), kolaborsi, kompromi dan akomodasi.Strategi yang paling ideal adalah strategi kompromi di mana merupakan strategi penanganan konflik yang efektif dari sisi penyelesaian tugas (task oriented) maupun dalam menjaga dan meningkatkan hubungan interpersonal maupun sosial (relation orinted). Strategi kolaborasi dan kompromi merupakan strategi terbaik karena merupakan win-win solution bagi kedua belah pihak yang sedang konflik.

\section{Dampak Konflik}

Konflik dapat dikatakan seperti dua mata sisi sebuah koin, satu sisi berdampak positif, sisi yang lain berdampak negatif (Susanto, 2007). Dampak positifnya dapat meningkatkan pencapaian karena adanya gairah atau semangat (motivasi meningkat), pemecahan masalah dan kepekaan mengindentifikasi masalah meningkat, ikatan kelompok lebih erat, kreativitas meningkat, untuk memodifikasi sistem, 
membantu mencapai tujuan organisasi, dan penyesuaian diri pada kenyataan.Dampak negatifnya adalah produktivitas menurun, kepercayaan berkurang bahkan hilang, terbentuk kelompok-kelompok kubu, menimbulkan biaya dalam organisasi, kelelahan mental dan fisik, terbaginya perhatian, timbul masalah moral, dan hilangnya sinergi dalam perusahaan.

\section{Penyelesaian Konflik}

Astrachan, McMillan, \& Pieper (2012) menyatakan mekanisme untuk menyelesaikan konflik ada yang bersifat sukarela (voluntary) dan tidak sukarela (involuntary). Penyelesaian konflik secara sukarela (voluntary) dilakukan melalui arbitration (menyampaikan perselisihan kepada konsultan) atau settlement agrrement (pernyataan formal secara tertulis), business spin-offs (menyelesaikan konflik dengan cara membagi bisnis menjadi beberapa bagian), buyout of dissenting shareholder (membeli sahamsaham pemilik yang lain) atau menjual bisnis ke pihak ketiga. Laurence \& Mastamu (2015) mengatakan penyelesaian konflik secara tidak sukarela (involuntary) bisa dilakukan dengan penyelesaian di pengadilan (court-ordered solution) atau memaksa pemilik lain untuk menjual saham-sahamnya (buy-out).

\section{METODE ANALISIS DATA}

Metode yang digunakan dalam menganalisis penelitian ini adalah kualitatif (Istijanto, 2010) mengatakan penelitian kualitatif adalah penelitian yang memaparkansuatu karakteristik tertentu dari sebuah fenomena dengan jenis data yang tidak terstruktur dalam arti variasi data yang diberikan oleh sumbernya sangat beragam. Fenomena konflik yang diteliti yaitu dengan mencari dan menggali lebih dalam sumber konflik dan bagaimana penyelesaian konfliknya. Subjek penelitian yaitu perusahaan keluarga yang bergerak di bidang perkebunan yang berdiri sejak tahun 2008.

Sampel dalam penelitian ini adalah pihak internal dalam perusahaan yang memangku jabatan top management. Narasumbernya terdiri dari dua orang yaitu:

a. Narasumber pertama adalah pemimpin perusahaan (direktur) sebagai pemangku jabatan tertinggi, dan

b. Narasumber kedua adalah istri dari direktur, beliau sebagai finance manager.

Analisis data yang digunakan adalah dengan cara deskriptif. Sedangkan sumber data yang digunakan terdiri dari dua sumber. a. Sumber data primer. Sumber utama penelitian adalah narasumber yang berasal dari pihak-pihak internal perusahaan yang terlibat dalam konflik (narasumber pertama dan kedua). Dalam hal ini peneliti langsung berinteraksi dengan narasumber sehingga bisa mengumpulkan banyak informasi fenomena konflik yang terjadi.

b. Sumber data sekunder. Data sekunder adalah data yang dikumpulkan oleh pihak lain sebelumnya. Data yang diperoleh yaitu berupa dokumen perusahaan dan observasi langsung selama proses penelitian.

Prosedur pengumpulan data adalah dengan wawancara secara langsung dan individual melalui tatap muka dengan narasumber.

\section{Hasil dan Pembahasan}

Perkebunan $\mathrm{X}$ adalah perusahaan keluarga yang termasuk dalam perusahaan keluarga kategori Family Business Enterprise (FBE). Hal ini disebabkan karena untuk posisi-posisi terpenting di perusahaan seperti pimpinan, manajer keuangan dan manajer operasional dipegang oleh anggota keluarga.

Dari hasil penelitian yang mencakup observasi langsung dan hasil wawancara dengan narasumber, maka ditemukan tiga jenis konflik yang ditemukan dalam perusahan dan ini sesuai dengan ulasan teori dalam Susanto (2007). Ketiga konflik tersebut adalah sebagai berikut.

1. Konflik antara kepentingan bisnis dan kepentingan keluarga. Hal ini disebabkan karena tidak jelasnya struktur organisasi dalam perusahaan sehingga dalam pengambilan keputusan bisa dilakukan berbagai pihak, tentunya menjadi ambigu antara kepentingan bisnis dan kepentingan keluarga. Konflik ini didasari juga adanya perbedaan antara nilai yang dianut oleh narasumber yaitu antara nilai keluarga (kesuksesan bisnis adalah untuk keluarga) dengan nilai bisnis (kesuksesan bisnis adalah untuk perusahaan).

2. Konflik antara anggota keluarga. Komunikasi yang kurang lancar, menjadi hambatan terbesar dalam manajemen bisnis keluarga, konflik antar keluarga membuat atmosfer kerja menjadi tidak nyaman dan menghambat produktivitas. Dalam perusahaan ini setiap permasalahan yang dihadapi tidak segera diselesaikan kasus per kasus, sehingga bebannya menumpuk pada saat load pekerjaan sedang tinggi. Hal ini yang memicu konflik semakin membesar. 
3. Konflik antara keluarga dan karyawan. Dalam perusahaan ini kerap kali terjadi karena adanya miss communication antara atasan dan karyawan yang disebabkan tidak adanya standard operating prosedur yang jelas dan juga juga adanya dua perintah yang berbeda dari atasan yang satu dengan atasan yang lain terhadap satu bagian divisi yang sama.

Dari ketiga jenis konflik yang ditemukan yang menjadi akar utama konflik adalah konflik antara keluarga dalam hal ini adalah antarakeluarga inti. Hal ini disebabkan dikarenakan baik narasumber pertama maupun narasumber kedua sebagai pemangku jabatantop management dalam perusahaan keluarga ini kurang memiliki kompetensi di bidangnya sehingga kurang menguasai bagiannya dengan baik. Sehingga mengakibatkan overlapping pekerjaan yang memicu timbulnya banyak mismanagement dan miscommunication baik antara narasumber maupun dengan karyawan.

Hasil analisis lebih dalam dari obeservasi dan wawancara dan didukung juga melalui pengumpulan data sekunder lainnya ditemukan penyebab lain dari konflik dalam perusahaan keluarga. Penyebab itu adalah sebagai berikut.

a. Penyebab ini dapat menjadi sumber konflik karena perbedaan pemahaman dalam menerima informasi melalui kata dan kalimat yang diucapkan hal ini menyebabkan pertukaran informasi menjadi tidak memadai. Astrachan et al. (2012) mengatakan bahwa komunikasi yang baik dalam keluarga dan perusahaan dapat terjadi apabila dapat menghindari kesalahan dalam menafsirkan pesan. Dalam komunikasi, konotasi kata dapat menimbulkan makna berbeda yang berpotensi menimbulkan konflik. Dalam perusahaan keluarga ini banyak salah penafsiran antar pihak yang mengalami konflik dikarenakan kurangnya keterbukaan dan kepercayaan antara yang satu dengan yang lain.

b. Penyebab lain dari konflik perusahan ini adalah tentang struktur. Pengambil keputusan dalam setiap kebijakan lebih mayoritas diambil bukan oleh pemangku struktur tertinggi (direktur) namun oleh manajer keuangan dikarenakan manajer keuangan menguasai total cash flow atau arus keuangan dan budgeting.Setiap bagian terkait di dalam perusahaan bergantung dengan keuangan. Peran manajer keuangan menjadi lebih besar dibandingkan direktur. yang menyebabkan sering terjadinya konflik karena narasumber pertama (direktur) merasa perannya dilangkahi dan tidak memiliki power dan wewenang dalam perusahaan.

c. Hal ini mencakup kepribadian, emosi, dan nilai-nilai. Jenis kepribadian tertentu seperti individu yang sangat otoriter memiliki potensi memunculkan konflik, emosi juga dapat menyebabkan konflik. Narasumber memiliki tingkat kepribadian dan emosi yang cukup labil dan emosional, mudah marah, tidak bisa menyalurkan emosi dengan baik, sehingga cenderung berprasangka negatif dan otoriter. Sehingga pola pikir tersebut mendasari tindakan dan keputusan yang diambil dan dilaksanakan di dalam perusahaan.

Adapun dampak konflik yang diakibatkan lebih banyak berdampak negatif bagi perusahaan. Beberapa contoh dampak negatif tersebut adalah sebagai berikut.

1. Proses pengambilan keputusan menjadi tertunda. Hal ini tentunya menghambat arus barang dan arus uang dalam perusahaan.

2. Munculnya kelompok-kelompok kubu diantara karyawan. Hal ini mengakibatkan suasana kerja dan astmosfer kerja menjadi tidak sehat. Pada saat mengerjakan pekerjaan menjadi tidak produkif.

3. Terhambatnya penanganan masalah dalam pekerjaan dikarenakan tidak ada kata sepakat antara top manajemen (narasumber) sehingga memperlambat pengembangan bisnis dan terhambat juga perluasan baik kuantitas produksi dan pasar sasaran.

\section{SIMPULAN}

Berdasarkan analisis data dari narasumber dapatdiambil simpulan bahwakonflik yang berdampak negatif harus segera diselesaikan. Untuk menyelesaikan konflik tentunya dengan cara berusaha mencari titik temu terhadap konflik yang terjadi. Sebelum penelitian ini dilakukan, kedua belah pihak cenderung menghadapi konflik dengan strategi penghindaran (avoidance), namun cara ini sangat tidak efektif dan tidak menyelesaikan akar dari konflik tersebut yang mengakibatkan konflik semakin berlarut-larut.

Simpulan dari penelitian ini juga menemukan bahwa konflik yang terjadi dalam perusahaan keluarga adalah tentang hubungan dengan struktur organisasi dan antara anggota 
organisasi. Tidak ada penegasan hak dan tanggung jawab di dalam struktur organisasi mereka, sehingga seringkali terjadi tupang tindih bahkan double powerantara direktur dengan finance manager. Dengan hasil analisis yang dilakukan maka peneliti memberikan saran sekaligus solusi penyelesain konflik kepada narasumber untuk membina kerjasama dengan konsultan bisnis (arbitrator) dalam hal ini melalui peranan universitas dan juga melakukan penerimaan manajer operasional dari profesional (pekerja bukan merupakan anggota keluarga). Kedua saran di atas telah dilaksanakan dan berbuah hasil yang cukup signifikan dimana secara bertahap pemilik bisnis dapat menyelesaikan beberapa konflik yang ada.Agar manajemen perusahaan semakin terstrukur maka diperlukanpembuatan struktur organisasi dan SOP (Standard Operating Procedure), maka pihak universitas mengadakan pengabdian masyarakat untuk merapihkan struktur dan pembuatan SOP di dalam perusahaan tersebut. Hal ini sangat membantu pemangku manajemen perusahaan dan karyawan mengetahui prosedur secara lebih jelas dan terperinci dari sebelumnya.

Adapun penyelesaian konflik internal adalah dengan mengembalikandan memperjelas narasumber pertama (direktur) sebagai pemimpin tertinggi dan pengambil keputusan tertinggi yang tentutan memiliki kewenangan lebih besar dari pemangku lain (narasumber kedua yaitu finance manager). Dapat disimpulkan strategi yang dipakai untuk mengelola dan menyelesaikan konflik yaitu menggunakan strategi kolaborasi dan kompromi yang dimana akan memberikan win-win solution bagi kedua belah pihak.

\section{KETERBATASAN PENELITIAN DAN SARAN}

Penelitian ini hanya mendalami satu perusahaan saja, sehingga hasil penelitian terbatas hanya menggambarkan perusahaan tersebut.Adapun beberapa saran yang dapat diusulkan untuk penelitian mendatang adalah responden lebih dari satu perusahaan baik dari industri sejenis maupun industri tidak sejenis. Masa pencarian informasi lebih mendalam dan dalam jangka waktu yang lebih lama, sehingga bisa lebih spesifik dan terukur menggali informasi terkait. Untuk penelitian selanjutnya akan melakukan penelitian tentang manajemen konflik dalam perusahaan keluarga hendaknya dapat mengukur dampak konflik terhadap berbagai pihak baik imternal maupun eksternal secara holistik. Apabila konflik dalam perusahaan keluarga 140 semakin memburuk maka diperlukan peran konsultan untuk menengahi dan bersama-sama mencari jalan dan solusi terbaik secara profesional.

Saran lainnya yaitu dibutuhkan room for improvement bagi komunikasi dan pembaharuan kompetensi secara terbuka anggota keluarga dalam memimpin perusahaan. Menurut Astrachan et al. (2012), konflik muncul dari cinta dan kepedulian antaranggota keluarga satu dengan yang lainnya. Konflik dapat diredam dengan cara memperbanyak waktu keluarga atau pertemuan-pertemuan keluarga (family meetings) yang khusus membahas kondisi dan masa depan perusahaan maka diharapkan bisa menyelerasaskan visi misi narasumber sehingga diharapkan menimbulkan hubungan baik dan pemikiran yang sepaham tentang menjalankan usaha tersebut. Dalam mengelola bisnis juga diperlukan kejujuran anggota keluarga, termasuk mengenai masalah-masalah yang timbul, harapan-harapan dan rencana-rencana untuk masa depan.

\section{REFERENSI}

Aronoff, C.E., McClure, S.L., \& Ward, J.L. (2011). Business Succession: The Final Test of Greatness. Georgia: Family Enterprise Publisher.

Astrachan, J.H., McMillan, K.S., \& Pieper, T. M. (2012). Family Business. Marietta: Family Enterprise Publisher.

Carr, J.C. \& Hmieleski, K.M. (2015). Differences in the outcomes of work and family conflict between family and nonfamily businesses: An examination of business founders. Entrepreneurship Theory and Practice, 39(6), 1413-1432.

Corbetta, G. \& Salvato, C. (2012).Strategies for Longevity in Family Firms: A European Perspective. NewYork: Palgrave MacMillan.

Istijanto, F. (2010). Aplikasi Praktis Riset Pemasaran. Jakarta: Gramedia.

Kamus Besar Bahasa Indonesia. (2008). Jakarta: Pusat Bahasa.

Laurence, L. \& Mustamu, R. H. (2015). Manajemen Konflik dalam Perencanaan Suksesi Perusahaan Keluarga di Bidang Ekspedisi di Surabaya. Agora3(1), Surabaya: Universitas Kristen Petra.

Liliweri, A. (2005). Prasangka dan Konflik. Yogyakarta: LKIS Pelangi Aksara.

Lucky, E. O., Minai, M. S., \& Isaiah, A. O. (2011). A Conceptual Framework of 
Family Business Succession: Bane of Family Business Continuity. International Journal of Business and Social Science 2 (18).

Nurwantoro \& Sobirin. (2013). Analisis Kepemimpinan Perusahaan Keluarga. Jakarta: Raja Grafindo Persada.

Ruiz, E.J.Y. (2013). Family Business Conflict Degree in Business Administration ( $4^{\text {th }}$ Courses). Spain: Universitat Jaume I.

Susanto, A.B. (2007). Family Business. Edisi Pertama. Jakarta: The Jakarta Consulting Group.

Xi, J.M., Kraus, S., Kellermanns, F. \& Filser, M. (2015). Mapping the Field of Family Business Research: Past Trends and Future Directions. International Entrepreneurship and Management Journal, 11(1), 113-132. 
Jurnal Manajemen Maranatha — Vol. 18 Nomor 2, Mei (2019) 